\title{
Lightweight Concrete with an Agricultural Waste - Buckwheat Husk
}

\author{
Giedrius VAICKELIONIS *, Virginija VALANČIENE் \\ Department of Silicate Technology, Kaunas University of Technology, Radvilenu str. 19, LT-50254 Kaunas, Lithuania \\ cross $^{\text {ref }}$ http://dx.doi.org/10.5755/j01.ms.22.1.8662
}

Received 11 November 2014; accepted 31 January 2015

\begin{abstract}
This paper presents a parametric experimental study which investigates the potential use of buckwheat husk wastes (as an aggregate in concrete) and opoka combination for producing a lightweight composite. The study was carried out to investigate the influence of the buckwheat husk extract on the setting and hardening of pastes in which cement was partially replaced by 0,33 , or $50 \%$ of natural pozzolana. The kinetics of hydration up to $48 \mathrm{~h}$ was studied using isothermal conduction calorimetry. Some of the physical and mechanical properties of buckwheat husk concrete with various levels of cement replacement of opoka without and with sand (part of buckwheat husk was replaced in the same volume of sand) were investigated.

Experimental data on the compressive strength of concrete utilizing buckwheat husk with and without sand and cement at varying proportions are presented. The results suggest that buckwheat husk may be used as an aggregate, particularly in lightweight concrete, panel and blocks for walls at a relatively cheaper price.

Key words: waste; buckwheat husk; cement; pozzolana; isothermal calorimetry; lightweight concrete.
\end{abstract}

\section{INTRODUCTION}

Isolation and low-cost materials are important for nonload-bearing and load-bearing lightweight concrete masonry units [1], especially for agricultural constructions because, in general, farm buildings are of one or two floors and carry low loads. Therefore, the strength of constructed buildings is not as important as heat isolation and construction cost [2].

Lightweight aggregate concretes are broadly divided into three groups based upon their use and physical properties: structural, structural/insulating, and insulating. The bulk density, thermal conductivity, and compressive strength ranges, normally associated with each class of concrete, are summarized in Table 1. The first group is termed low strength, corresponding to low density, and is mostly used for insulation purposes. The second group is of moderate strength and is used for filling and block concrete. The third group is structural lightweight concrete and is used in reinforced concrete [3]. Organic lightweight aggregate concrete is produced by replacing normal aggregate with organic aggregate in concrete or mortar, either partially or fully, depending on the requirements of strength and density.

Table 1. Lightweight aggregate concrete classified according to use and physical properties [3]

\begin{tabular}{|l|c|c|c|}
\hline \multirow{2}{*}{ Properties } & \multicolumn{3}{|c|}{ Lightweight aggregate concrete } \\
\cline { 2 - 4 } & insulating & $\begin{array}{c}\text { structural/ } \\
\text { insulating }\end{array}$ & structural \\
\hline $\begin{array}{l}\text { Concrete } \\
\text { density, } \mathrm{kg} / \mathrm{m}^{3}\end{array}$ & $240-800$ & $800-1440$ & $1440-1840$ \\
\hline $\begin{array}{l}\text { Compressive } \\
\text { strength, } \mathrm{MPa}\end{array}$ & $0.7-(2.0) 3.4$ & $(2.0) 3.4-17.0$ & $>17.0$ \\
\hline
\end{tabular}

\footnotetext{
* Corresponding author. Tel.: +370 37 300163; fax: +370 37300152 .

E-mail address: gievaic@ktu.lt (G. Vaickelionis)
}

To produce lightweight concrete, numerous methods can be used. The most popular method is the use of natural, synthetic or organic lightweight aggregates. Examples of lightweight aggregates are pumice, coal slag, flying ash, and various agricultural wastes and residues. It contains relatively large quantities of lignocellulosic materials available in the form of agricultural residues. The organic waste used in lightweight concrete is mainly of plant origin and includes rice and wheat husk, straw, sawdust, cork granules, coconut fibre and shell $[4,5]$.

A large quantity of lignocellulosic wastes is generated worldwide from various sources such as agriculture, construction, wood and furniture industries leading to environmental concerns. The use of these wastes in making cement-bonded construction materials can reduce the magnitude of the problems. However, in this effort, there are various restraints such as the compatibility of these wastes with cement and a limited composite strength [6].

In the course of growing and cleaning buckwheat grains, large amounts of wastes are formed (straw, husk, fine particles of grains). These agricultural wastes can be considered as valuable renewable raw materials for chemical, food, and pharmacological industries, suitable for the production of polysaccharides, cellulose, dyes and food additives, furfural, and drugs [7]. It has also been found that aqueous extracts of buckwheat straw and husk inhibit the corrosion of low-carbon steel [8]. However, until now, the main part of buckwheat wastes has not been used in chemical industry and is burnt in fields or used as a fuel for boilers, fillers for pillows, packing of fruits and fragile goods, and feed [9].

Much less data on these wastes are available as compared to the related products of rice processing. The buckwheat husk $(\mathrm{BH})$ contains more organic matter and significantly less inorganic matter in comparison to rice husk widely used in cement-bonded composites [5].

Polysaccharides obtained by successive extraction with water, ammonium oxalate, and sodium hydroxide 
from buckwheat and sunflower husks contain not only polysaccharide fractions, but also protein-polysaccharide complexes and low-molecular-weight compounds [10].

The extractability of the hemicellulose component strongly depends on the alkali concentration. Increasing the alkali concentration increases the total yield of hemicelluloses [11].

Polysaccharides extractable with water from buckwheat husk have a relatively high glucose content. Polysaccharides obtained by alkaline extraction have a more complex monosaccharide composition which consist of residues of rhamnose, arabinose, xylose, mannose, glucose, and galactose [7, 10, 11].

The polysaccharide (PS) content depends on the buckwheat husk plant strain and recovery procedure. The total yield of PSs from buckwheat husk varies from 3.2 to 6.3 wt.\% based on the dry raw material. The largest amount of polysaccharides is recovered by alkaline extraction and the smallest amount by aqueous extraction [12]. The yield of PSs from buckwheat wastes obtained in the extraction with water varies from 2.14 to 2.76 wt.\% [7].

Samples of a dry extract (DE) were obtained by evaporation of liquid extracts on a water bath. The yield of a dry extract of raw material and water mixture in the ratio of $1: 25$, depending on the concentration of extractive substances in the solution, is no less than $2 \%$ relative to the mass of the starting raw material. Such a low DE yield as compared with the amount of extractive substances in solution can be due to the presence of volatile components in the extract.

As Kuhne and Meier have reported [13], hemicelluloses cause the main inhibiting effects. The alkaline medium, which is caused by cement, decomposes hemicelluloses into the substances that negatively influence cement setting.

Collepardi et al. found that the addition of glucose, gluconate, or lignosulfonate stabilized ettringite in the $\mathrm{C}_{3} \mathrm{~A}$ - gypsum - lime system [14].

Buckwheat husk (BH) as an organic waste is a significant problem in buckwheat cultivating areas, because it is not used profitably and is generally burned after harvest, which causes environmental problems. The use of $\mathrm{BH}$ in concrete production may solve this environmental problem and provide an advantage in producing lightweight and low-cost concrete.

The aim of this study was to examine the effect of $\mathrm{BH}$ on the engineering properties of concrete.

An earlier work of one by us and colleagues [15] confirmed that in the production of lightweight concrete with sawdust or other fine organic agricultural additives the abundant usage of high-grade Portland cement is not rational, because the same amount of less active mineral binders or pozzolan mineral additive gives identical or even better results.

Opoka has been found [16] to be an efficient additive which reduces the harmful influence of hemicellulose on the hydration of Portland cement.

This paper gives a review of results of a recent research into the use of these wastes in making cementbonded composites for building materials.

\section{MATERIALS AND METHODS}

Buckwheat hulls (Fig. 1), from which extracts were prepared, sifted through a sieve in order to separate them from dust and other impurities as well as crops seeds. A fraction with a particle size of no less than $2 \mathrm{~mm}$ was selected for experiments. Then the husk samples were washed with water and dried in an open air to constant weight. Their moisture was about $6.87 \%$. The apparent density of buckwheat husk was about $125.5 \mathrm{~kg} / \mathrm{m}^{3}$.

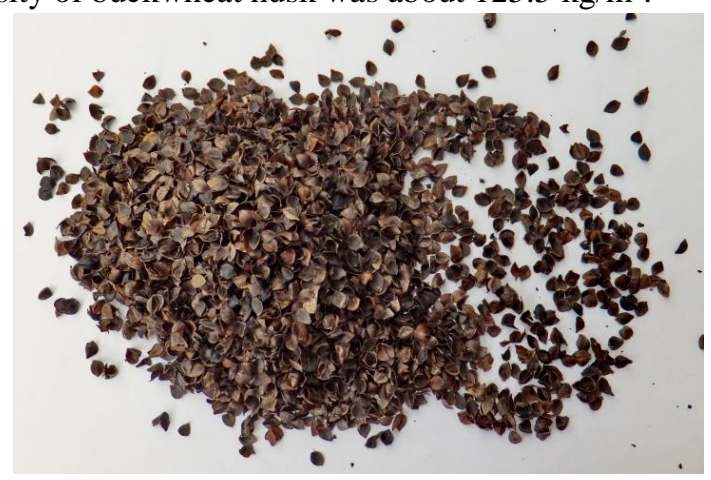

Fig. 1. Buckwheat husk

The buckwheat husk was poured with water (water extracts) and with saturated $\mathrm{Ca}(\mathrm{OH})_{2}$ solution (alkali extracts). A buckwheat husk sample was mixed with water at a ratio $1: 10$ by weight, the mixture was heated at $80-90{ }^{\circ} \mathrm{C}$ for $24 \mathrm{~h}$, and then the formed extracts were filtered. The concentration of buckwheat husk water extract was $0.4 \pm 0.04 \%$. Samples of a dry extract (DE) were obtained by evaporation of liquid extracts on a water bath. The yield of a dry extract at raw material was $4.4 \pm 0.2 \%$ relative to the mass of the starting raw material.

The presence of pigments in the soluble substances of buckwheat husk results in a different colour of extracts.

Lithuania contains abundant natural pozzolana called opoka, which consists of amorphous $\mathrm{SiO}_{2}$ and finely dispersed $\mathrm{CaCO}_{3}$ [17]. The composition of opoka (natural pozzolana) is presented in Table 2 and Table 3 . The pozzolana was ground in a laboratory mill to a specific surface area of $1200 \mathrm{~m}^{2} / \mathrm{kg}$ (determined by the Blaine method). The hydraulic activity of pozzolana was $220 \mathrm{mg}$ of $\mathrm{CaO} / \mathrm{g}$.

Table 2. Oxide composition of opoka

\begin{tabular}{|c|c|c|c|c|c|c|}
\hline \multicolumn{7}{|c|}{ Component, wt.\% } \\
\hline $\mathrm{SiO}_{2}$ & $\mathrm{Al}_{2} \mathrm{O}_{3}$ & $\mathrm{Fe}_{2} \mathrm{O}_{3}$ & $\mathrm{CaO}$ & $\mathrm{MgO}$ & $\mathrm{Na}_{2} \mathrm{O}$ & $\mathrm{K}_{2} \mathrm{O}$ \\
\hline 54.1 & 2.7 & 1.3 & 23.2 & 0.62 & 0.24 & 0.87 \\
\hline
\end{tabular}

The quantitative chemical composition analysis of Portland cement clinker by X-ray fluorescence spectroscopy (XRF) on a Bruker X-ray S8 Tiger WD spectrometer equipped with a $\mathrm{Rh}$ tube with energy of up to $60 \mathrm{keV}$. Powder samples were measured in Helium atmosphere and data were analysed with SPECTRA Plus QUANT EXPRESS standard software. The accuracy of measurements $-<0.01 \%$ (with standards).

The composition of the Ordinary Portland cement (OPC) clinker is shown in Table 4 and Table 5. The OPC was obtained by mixing OPC clinker and $4.5 \%$ gypsum (specific surface area determined by the Blaine method was $320 \mathrm{~m}^{2} / \mathrm{kg}$ ). 
Table 3. Mineral composition of opoka

\begin{tabular}{|c|c|c|c|c|c|c|c|}
\hline \multicolumn{9}{|c|}{ Component, wt.\% } \\
\hline Amorphous & Ancerite & Calcite & Cristobalite & Muscovite & Plagioclase & Quartz & Tridymite \\
$\mathrm{SiO}_{2} \cdot \mathrm{nH}_{2} \mathrm{O}$ & $\mathrm{Ca}(\mathrm{Fe}, \mathrm{Mg}, \mathrm{Mn})\left(\mathrm{CO}_{3}\right)_{2}$ & $\mathrm{CaCO}_{3}$ & $\mathrm{SiO}_{2}$ & $\mathrm{KAl}_{2}\left(\mathrm{AlSi}_{3} \mathrm{O}_{10}\right)(\mathrm{F}, \mathrm{OH})_{2}$ & $\mathrm{NaAlSi}_{3} \mathrm{O}_{8}$ & $\mathrm{SiO}_{2}$ & $\mathrm{SiO}_{2}$ \\
\hline 22.2 & 1.3 & 36.1 & 19.2 & 4.1 & 1.1 & 12.0 & 4.0 \\
\hline
\end{tabular}

Table 4. Oxide composition of Portland cement clinker

\begin{tabular}{|c|c|c|c|c|c|c|}
\hline \multicolumn{7}{|c|}{ Component, wt.\% } \\
\hline $\mathrm{SiO}_{2}$ & $\mathrm{Al}_{2} \mathrm{O}_{3}$ & $\mathrm{Fe}_{2} \mathrm{O}_{3}$ & $\mathrm{CaO}$ & $\mathrm{MgO}$ & $\mathrm{Na}_{2} \mathrm{O}$ & $\mathrm{K}_{2} \mathrm{O}$ \\
\hline 19.72 & 5.41 & 4.21 & 62.76 & 3.41 & 0.16 & 1.08 \\
\hline
\end{tabular}

Table 5. Mineral composition of OPC clinker

\begin{tabular}{|c|c|c|c|}
\hline \multicolumn{3}{|c|}{ Component, wt.\% } \\
\hline $\mathrm{C}_{3} \mathrm{~S}$ & $\beta-\mathrm{C}_{2} \mathrm{~S}$ & $\mathrm{C}_{3} \mathrm{~A}$ & $\mathrm{C}_{4} \mathrm{AF}$ \\
\hline 63.19 & 8.87 & 7.21 & 12.81 \\
\hline
\end{tabular}

Besides the OPC pastes for control purposes, two groups of pozzolana (opoka) incorporating specimens with cement replacement ratios of 33 and $50 \%$ by weight were prepared and formed using the standard water and buckwheat husk extract (Table 6). The monitoring of consistency and setting time was directly carried out using a Vicat apparatus.

Table 6. Composition of specimens of cement pozzolana (B) paste mix with water and buckwheat husk extract

\begin{tabular}{|c|c|c|c|}
\hline Mix no. & OPC, $\%$ & Opoka, $\%$ & $\mathrm{~W}(\mathrm{E}) / \mathrm{B}$ \\
\hline M1W & 100 & 0 & 0.255 \\
\hline M2W & 67 & 33 & 0.345 \\
\hline M3W & 50 & 50 & 0.425 \\
\hline M1E & 100 & 0 & $0.255^{*}$ \\
\hline M2E & 67 & 33 & $0.345^{*}$ \\
\hline M3E & 50 & 50 & $0.425^{*}$ \\
\hline * Buckwheat husk extract concentration was $0.9 \%$. \\
\hline
\end{tabular}

Infrared spectra were recorded using a PerkinElmer Fourier transform-infrared (FT-IR) system Spectrum X spectrometer. Tablets were prepared from $1 \mathrm{mg}$ of the sample and $200 \mathrm{mg}$ of $\mathrm{KBr}$. The spectral analysis was performed in the range of $4000-400 \mathrm{~cm}^{-1}$ with a spectral resolution of $1 \mathrm{~cm}^{-1}$.

An eight channel TAM Air III isothermal calorimeter was used to investigate the heat evolution rate of the cement-opoka binding material (B). Glass ampoules $(20 \mathrm{ml})$ each containing $3 \mathrm{~g}$ dry cementitious material were placed in the calorimeter and the injection units for each ampoule filled with amounts of water (buckwheat husk extract) equivalent to a $\mathrm{W}(\mathrm{E}) / \mathrm{B}$ ratio of 0.5 . After a steady temperature of $25^{\circ} \mathrm{C}$ had been reached, the water was injected into the ampoules and mixed inside the calorimeter with the dry material for $20 \mathrm{~s}$ (frequency $2-3 \mathrm{~s}^{-1}$ ). The heat evolution rate was then measured over a period of $50 \mathrm{~h}$. Repetition of the measurements showed deviations in total heat below $3 \%$ for samples of similar type. Apart from the first minutes of water additive and mixing, the heat evolution rates were essentially identical. The accuracy of measurement $-0.03 \mathrm{~W} / \mathrm{g}$.

The buckwheat husk concrete specimens were formed using the OPC (Table 4 and Table 5) without and with sand (part of buckwheat husk was replaced by the same volume of sand). The size of the specimens used for all the tests was $40 \times 40 \times 160 \mathrm{~mm}$. The concrete was then batched with the composition shown in Table 7. All concrete mixes had the total binder (cement plus opoka) content of $680 \mathrm{~kg} / \mathrm{m}^{3}$.

For the first three days, the samples were kept in moulds at $20 \pm 1{ }^{\circ} \mathrm{C}$ and $100 \%$ humidity. Then the specimens were stored for 7, 28 days, and 3 months in a chamber at $20^{\circ} \mathrm{C}$ and a $95 \%$ humidity.

The physical properties of the pastes and the strength of mortars were determined in accordance with LST EN 196-3:2005+A1:2009 [18] and LST EN 1961:2007 [19], respectively.

The moisture content of samples was determined on the wet basis $W_{w b}$ :

$$
W_{w b}=\frac{m-m_{d r y}}{m} \cdot 100 \%,
$$

where $m$ is the mass of a wet sample, and $m_{d r y}$ is the mass of a dry specimen.

The X-ray diffraction (XRD) data were collected with a DRON-6 powder X-ray diffractometer with the BraggBrentan geometry, using $\mathrm{Ni}$-filtered $\mathrm{CuK} \alpha$ radiation operating at a voltage of $30 \mathrm{kV}$ and an emission current of $20 \mathrm{~mA}$. The step-scan covered the angular range of 5$60^{\circ}(2 \theta)$ in steps of $2 \theta=0.02^{\circ}$.

Table 7. Actual mix proportions for $1 \mathrm{~m}^{3}$ lightweight concrete

\begin{tabular}{|c|c|c|c|c|c|}
\hline \multirow{2}{*}{ Concrete mixture } & \multicolumn{5}{|c|}{ Material content $(\mathrm{kg})$ for $1 \mathrm{~m}^{3}$ of concrete mixture } \\
\hline & Buckwheat husk & Cement & Opoka & Sand & Water \\
\hline & \multicolumn{5}{|c|}{ Without sand } \\
\hline CRM1 & 170 & 680 & - & - & 455 \\
\hline CRM2 & 170 & 453 & 227 & - & 455 \\
\hline \multirow{2}{*}{ CRM3 } & 170 & 340 & 340 & - & 455 \\
\hline & \multicolumn{5}{|c|}{ With sand } \\
\hline CRM1S & 130 & 680 & - & 390 & 455 \\
\hline CRM2S & 130 & 453 & 227 & 390 & 455 \\
\hline CRM3S & 130 & 340 & 340 & 390 & 455 \\
\hline
\end{tabular}




\section{RESULTS AND DISCUSSIONS}

\subsection{Investigation of the fresh buckwheat husk extracts}

The husk was treated under two different conditions: neutral (water) and alkali (saturated $\mathrm{Ca}(\mathrm{OH})_{2}$ solution). In order to find out the influence of the extraction conditions on the extract composition, an alkaline extract was prepared. It resulted in an alkaline medium during the preparation of buckwheat cement concrete and dissolved the materials present in the buckwheat husk. The alkaline buckwheat husk extract was prepared analogously to the aqueous one; in this case, the saturated calcium hydroxide was used. The results of this investigation are presented in Fig. 2 and Table 8.

Fig. 2 shows infrared spectra (IR) measured for two DE samples obtained from aqueous and alkali extracts of BH. The IR spectra of aqueous and alkali extracts of buckwheat husk contain groups of different intensity bands in the following frequency ranges $\left(\mathrm{cm}^{-1}\right)$ : 3600-2935, $1750-1516,1450-1260,1150-1020$, and $\sim 700-400$, which are typical of polysaccharides of plant origin, including the buckwheat waste [8]. The transmission bands in the $1200-800 \mathrm{~cm}^{-1}$ region give information about the polysaccharide types present [11]. The absorption bands were identified using the available structural-spectroscopic data on polysaccharides [12].

A comparison of the data of IR spectroscopy of dry materials existing in buckwheat husk with the results presented in the literature $[10,11]$ has shown that they are almost identical, implying the prevalence of various polysaccharides in aqueous and alkaline extracts of buckwheat husks. No more exact composition of buckwheat husk extracts has been determined, and data presented in the literature were used.

At the second stage of the experiment, we investigated the influence of the buckwheat husk extract on the setting and hardening of pastes in which cement was partially replaced by 0,33 , or $50 \%$ of natural pozzolana. All replacements were made by the mass of cement.
Table 8. IR absorption maxima of dry buckwheat husk extract samples

\begin{tabular}{|c|c|c|}
\hline \multirow[b]{2}{*}{$\begin{array}{c}\text { Assignment } \\
{[8,9]^{*}}\end{array}$} & \multicolumn{2}{|c|}{ Wave number $v, \mathrm{~cm}^{-1}$} \\
\hline & $\begin{array}{l}1-\mathrm{DE} \text { from an } \\
\text { aqueous extract of } \\
\text { buckwheat husk }\end{array}$ & $\begin{array}{l}2-\mathrm{DE} \text { from an alkali } \\
\text { extract of buckwheat } \\
\text { husk }\end{array}$ \\
\hline 1 & 3404 & 3384 \\
\hline 2 & 2934 & 2335 \\
\hline 3 & 1631 & 1619 \\
\hline 4 & $1409,1324,1259$ & 1420 \\
\hline 5 & 1101,1024 & 1125,1052 \\
\hline 6 & 790,538 & $670,618,469$ \\
\hline 7 & - & $2496,1420,865$ \\
\hline \multicolumn{3}{|c|}{$\begin{array}{l}* 1-\mathrm{OH} \text { stretching vibrations in } \mathrm{CHOH} \text { and } \mathrm{CH}_{2} \mathrm{OH} \text { groups; } 2- \\
\text { alkyl groups' stretching vibrations; } 3-\mathrm{OH} \text { bending vibrations, } \\
\mathrm{C}=\mathrm{O} \text { stretching vibrations in carbonyl and carboxy groups; } 4- \\
\text { group of bands including } \mathrm{C}-\mathrm{H} \text { bending modes: in-plane, internal } \\
\text { (scissor), and external (wagging); } 5-\text { stretching vibrations of } \mathrm{C}- \\
\mathrm{OH} \text { and } \mathrm{C}-\mathrm{O}-\mathrm{C} \text { bonds in polysaccharides; } \\
6-\text { group of bands including out-of-plane bending modes of } \mathrm{OH} \\
\text { groups and pulsation vibrations of pyranose rings [11, 12]; } 7- \\
\mathrm{CO}_{3}^{2-} \text { groups' vibrations. }\end{array}$} \\
\hline
\end{tabular}

\subsection{Investigations of the initial and the final setting times}

The hydration characteristics of buckwheat husk extract-modified cement specimens were determined by measuring the initial and the final setting times (Table 9).

The initial and the final setting times of the control cement were estimated to be 90 and $150 \mathrm{~min}$, respectively. Both initial and final setting times are increased the cement paste mixed with the extract. The initial and the final setting times were $160 \mathrm{~min}$ and $330 \mathrm{~min}$, respectively.

When part of cement was replaced with opoka and these mixes were prepared with water, the initial and the final setting times slightly changed as compared with the control cement paste. Thus, the initial and the final setting times varied within 95-80 min (initial) and 165-160 min (final), respectively, when the opoka content in the binder was 33 or $50 \mathrm{wt} \%$.

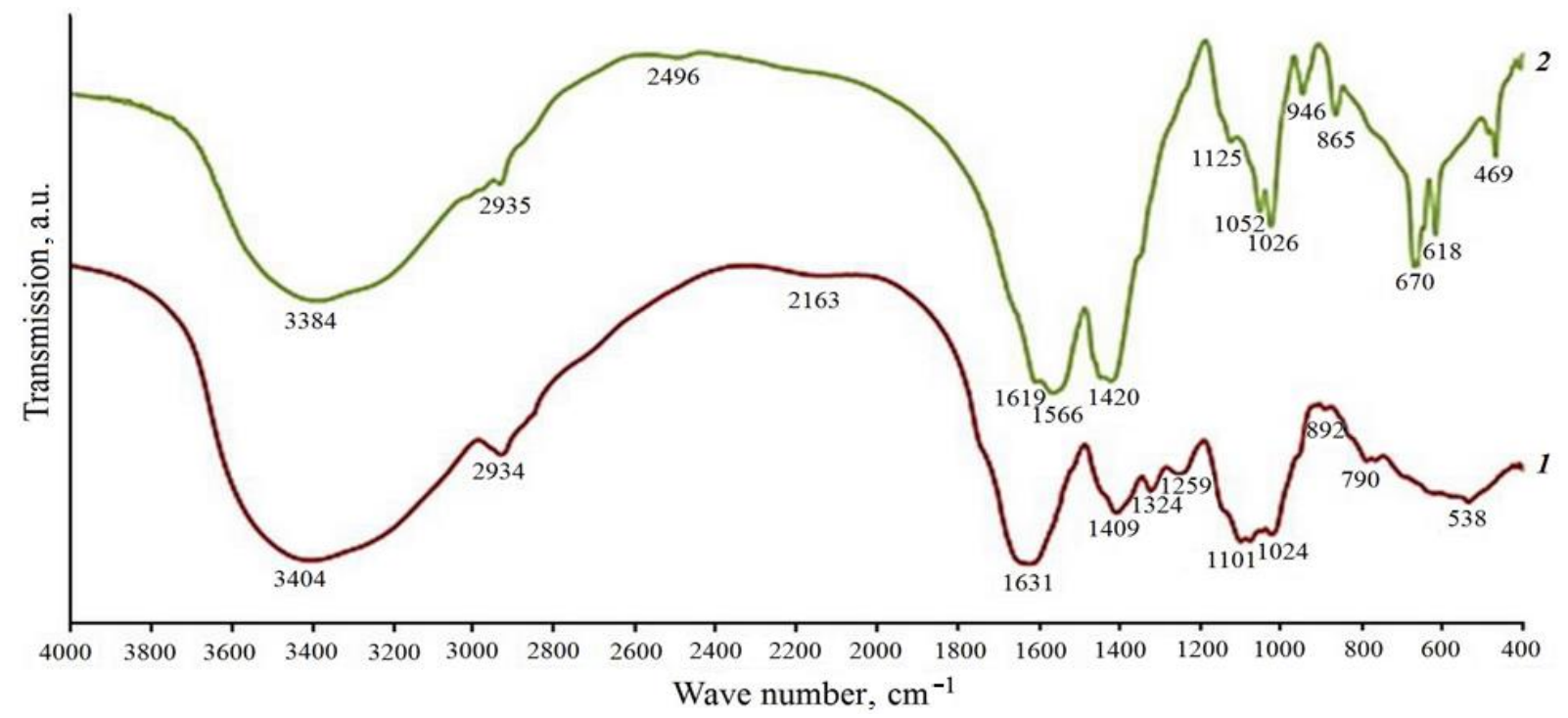

Fig. 2. The Fourier transform-infrared (FT-IR) spectrum of DE samples obtained from aqueous (1) and alkali (2) extracts of buckwheat husk 
Table 9. Initial and final sets of cement pozzolana paste mix with water and buckwheat husk extract

\begin{tabular}{|c|c|c|}
\hline Mix & Initial set time & Final set time \\
\hline \multicolumn{3}{|c|}{ Mixing with water } \\
\hline M1W & $90 \mathrm{~min}$ & $150 \mathrm{~min}$ \\
\hline M2W & $95 \mathrm{~min}$ & $165 \mathrm{~min}$ \\
\hline M3W & $80 \mathrm{~min}$ & $160 \mathrm{~min}$ \\
\hline \multicolumn{3}{|c|}{ Mixing with extract } \\
\hline M1E & $160 \mathrm{~min}$ & $330 \mathrm{~min}$ \\
\hline M2E & $75 \mathrm{~min}$ & $205 \mathrm{~min}$ \\
\hline M3E & $60 \mathrm{~min}$ & $195 \mathrm{~min}$ \\
\hline
\end{tabular}

However, when these binders with opoka were prepared with the buckwheat husk extract, their initial setting times significantly decreased (to 75 and $60 \mathrm{~min}$, respectively). The initial setting time of these specimens with opoka is shorter than of analogous specimens prepared with water. Opoka also minimizes the influence of extracts on the cement final setting time to 205 and $195 \mathrm{~min}$, respectively, but it remains longer as compared with specimens prepared with water.

\subsection{Investigation of isothermal calorimetry}

The process of the hydration of OPCs is commonly subdivided into several periods: initial (I), induction (II),
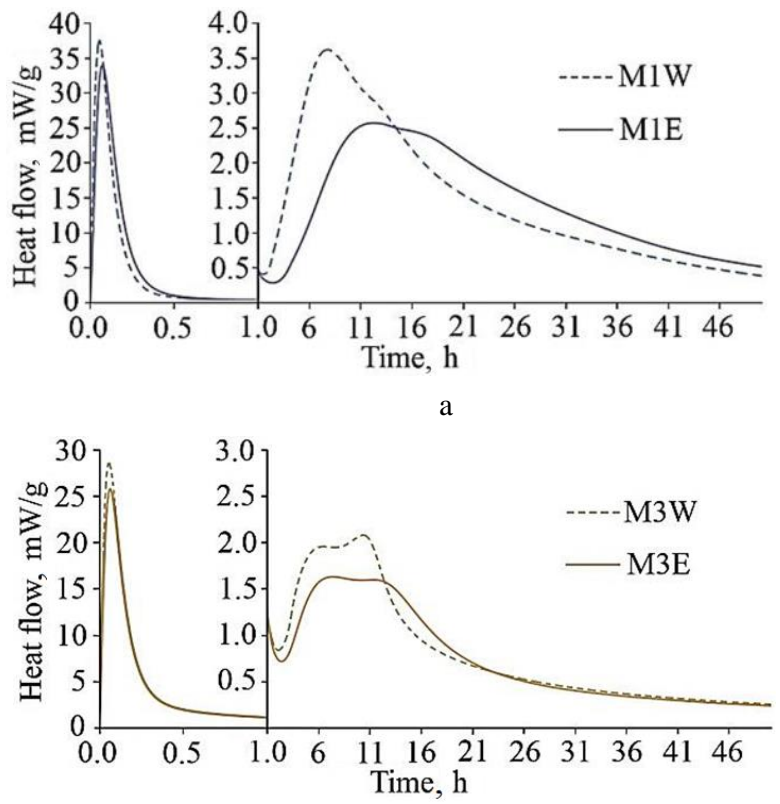

c acceleration (III), and retardation (IV). It is possible to sum up the acceleration and the retardation periods into the "main period". The calorimetric curve of many OPCs displays two significant heat flow maxima during the main period (Fig. 3).

The first is attained several hours after the beginning of the acceleration period, while the second one appears during the deceleration period.

The heat released during the first maximum of heat flow (called the "silicate reaction peak") is mainly attributed to the heat release from the silicate reaction, which includes the dissolution of $\mathrm{C}_{3} \mathrm{~S}$ and the precipitation of portlandite and $\mathrm{C}-\mathrm{S}-\mathrm{H}$ phase. The second heat flow maximum (called the "sulfate depletion peak") is characterized by heat release due to the dissolution of $\mathrm{C}_{3} \mathrm{~A}$ and the secondary formation of ettringite [20-22].

Three different periods of time were defined as proposed by Sauvat et al. [23], i.e., $t_{1}, t_{2}$ and $t_{3}$, which correspond to the minimal dormant time, the first peak time, and the second peak time, respectively. The increased amount of pozzolana (from $33 \%$ to $50 \%$ ) prolongs the dormant period to 1.69 and 2.05 hours in comparison with the control cement specimens without opoka, whose dormant period is 1.46 hours (Table 10).

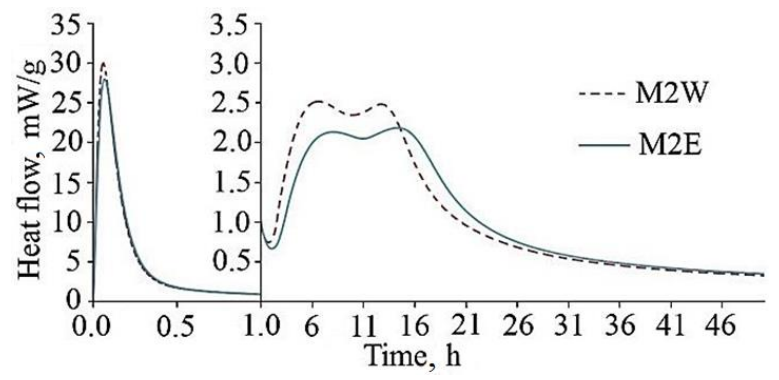

b

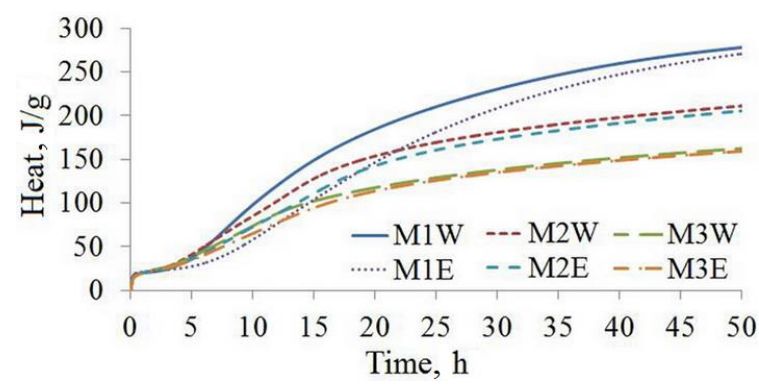

d

Fig. 3. Calorimetric curves of thermal flow in Ordinary Portland cement pastes (a) and in pastes where cement was partially replaced by $33 \%$ (b) or $50 \%$ (c) of opoka prepared using standard water and buckwheat husk extract, and hydration heat in the samples (d)

Table 10. The influence of extracts on hydration characteristic times and enthalpy

\begin{tabular}{|c|c|c|c|c|c|c|c|c|c|}
\hline \multirow[b]{2}{*}{ Mix } & \multicolumn{2}{|c|}{ First exothermal effect } & \multirow[b]{2}{*}{$\begin{array}{l}\text { Induction } \\
\text { period } t_{1}, \mathrm{~h}\end{array}$} & \multicolumn{2}{|c|}{$\begin{array}{l}\text { Second exothermal } \\
\text { effect } t_{2}\end{array}$} & \multicolumn{2}{|c|}{$\begin{array}{c}\text { Third exothermal effect } \\
t_{3}\end{array}$} & \multicolumn{2}{|c|}{$\begin{array}{c}\text { Heat of } \\
\text { hydration, } \mathrm{J} / \mathrm{g}\end{array}$} \\
\hline & Peak time, $\mathrm{h}$ & $\begin{array}{l}\text { Heat } \\
\text { flow, } \\
\mathrm{mW} / \mathrm{g}\end{array}$ & & Peak time, $\mathrm{h}$ & $\begin{array}{l}\text { Heat } \\
\text { flow, } \\
\mathrm{mW} / \mathrm{g}\end{array}$ & Peak time, $\mathrm{h}$ & $\begin{array}{l}\text { Heat } \\
\text { flow, } \\
\mathrm{mW} / \mathrm{g}\end{array}$ & $24 \mathrm{~h}$ & $48 \mathrm{~h}$ \\
\hline M1W & 0.056 & 37.60 & 1.46 & 7.75 & 3.63 & 12.8 & 2.80 & 205.5 & 274.9 \\
\hline M1E & 0.075 & 34.04 & 2.37 & 12.87 & 2.58 & 17.5 & 2.42 & 174.9 & 266.8 \\
\hline M2W & 0.061 & 30.07 & 1.69 & 6.56 & 2.52 & 12.7 & 2.49 & 166.5 & 208.5 \\
\hline M2E & 0.066 & 28.08 & 1.98 & 8.14 & 2.14 & 14.2 & 2.19 & 157.6 & 202.8 \\
\hline M3W & 0.061 & 28.62 & 2.05 & 6.39 & 1.96 & 10.3 & 2.09 & 126.8 & 160.3 \\
\hline M3E & 0.064 & 25.05 & 2.33 & 7.44 & 1.58 & 11.4 & 1.55 & 124.9 & 158.8 \\
\hline
\end{tabular}


In general, natural pozzolana seems to accelerate the hydration of $\mathrm{C}_{3} \mathrm{~S}$ (the $t_{2}$ peak time decreased from $7.75 \mathrm{~h}$ (control) to $6.56-6.39 \mathrm{~h}$ ). The acceleration of the early hydration of $\mathrm{C}_{3} \mathrm{~S}$ caused by pozzolana has been ascribed to the fineness of pozzolana particles, which offer a greater surface for the precipitation of $\mathrm{C}-\mathrm{S}-\mathrm{H}$ from the pore solution. In other words, acceleration is not due to the pozzolanic reaction which can be observed, at the very best, after several days.

The general rate of heat evolution-time curve of Portland cement shows that the rate of retardation does not change significantly with pozzolana incorporation. However, one peculiarity of this period that should be noted is related to the shoulder or the peak that results from the renewed ettringite AFt formation. As the amount of pozzolana incorporation is increased, the peak becomes extraordinarily high. In fact, this may be the delayed $\mathrm{C}_{3} \mathrm{~S}$ hydration peak due to an excessive amount of pozzolana present in the cement rather than an $\mathrm{AFt}$ peak, or a combination of both. Another possible reason would be the amount of gypsum being higher than necessary. The gypsum content is so adjusted in cements that $\mathrm{C}_{3} \mathrm{~A}$ forms ettringite while the cement paste is still plastic. Therefore, the excess gypsum might have resulted in the conversion of monosulfate phase into ettringite. This conversion may be responsible for the accentuated second peak in the rate of the heat evolution curve.

The buckwheat husk extract particularly delays and inhibits the Portland cement hydration and extends the induction period from $1.46 \mathrm{~h}$ for pure cement to $2.37 \mathrm{~h}$ for paste prepared using the buckwheat husk extract. The $t_{2}$ value increases from 7.75 to $12.87 \mathrm{~h}$ for the Portland cement pastes prepared with the buckwheat husk extract. This result confirms that the hydration of silicate phases is significantly delayed by buckwheat husk extractives.

Upon replacing part of the Portland cement with opoka, the influence of the buckwheat husk extract on the hydration of the binding material substantially changes. The calorimetric curves of Ordinary Portland cement replaced with $33 \%$ (Fig. 3 b) and $50 \%$ (Fig. 3 c) (by weight) of opoka pastes prepared using the standard water and buckwheat husk extract are similar (Fig. 3 b, c). Opoka additive minimized influence of buckwheat husk extract to cement hydration. In specimens with opoka are hydrating a less amount of $\mathrm{C}_{3} \mathrm{~S}$ (33 and $50 \%$ (by weight) of cement replaced by opoka), but until $19 \mathrm{~h}$ and $13 \mathrm{~h}$ hydration (respectively) they emit more heat than pure cement prepared with the extract (Fig. 3 d).

\subsection{Investigation of the buckwheat husk concrete properties}

At a corresponding time, the compressive strength of the wet buckwheat husk concrete samples was measured. Crushed samples were weighed and then dried at a temperature of $80{ }^{\circ} \mathrm{C}$ until a constant mass.

Concrete samples without sand addition are relatively weak and brittle. The replacement of part of buckwheat husk by sand increases the density of the concrete and at the same time significantly increases the compressive strength of a sample. After the test, such sample deforms but not crumbles. A summary of the test results regarding the compressive strength, moisture content and dry density of buckwheat husk concrete is given in Table 11 .

Table 11. The test results of dry density and compressive strength of the wet buckwheat husk concrete samples

\begin{tabular}{|c|c|c|c|c|}
\hline \multirow{2}{*}{$\begin{array}{l}\text { Concrete } \\
\text { mixture }\end{array}$} & \multirow{2}{*}{$\begin{array}{c}\text { Dry } \\
\text { density, } \\
\mathrm{kg} / \mathrm{m}^{3}\end{array}$} & \multicolumn{3}{|c|}{$\frac{\text { Compressive strength, MPa }}{\text { Moisture content of samples, } \%}$} \\
\hline & & 3 day & 7 day & 28 day \\
\hline CRM1 & 925 & $\frac{1.58}{22.83}$ & $\frac{2.51}{15.88}$ & $\frac{3.01}{16.90}$ \\
\hline CRM2 & 845 & $\underline{1.68}$ & $\frac{2.53}{14.82}$ & $\frac{3.08}{14.38}$ \\
\hline CRM3 & 809 & $\frac{1.33}{22.06}$ & $\frac{2.16}{16.02}$ & $\frac{2.91}{16.30}$ \\
\hline & & 7 day & 28 day & 3 month \\
\hline CRM1S & 1410 & $\underline{3.87}$ & $\frac{5.86}{15.22}$ & $\frac{7.45}{19.99}$ \\
\hline CRM2S & 1309 & $\frac{5.53}{22.22}$ & $\frac{7.35}{17.70}$ & $\frac{8.56}{25.95}$ \\
\hline CRM3S & 1263 & $\frac{4.79}{22.86}$ & $\frac{6.76}{19.68}$ & $\frac{8.19}{23.53}$ \\
\hline
\end{tabular}

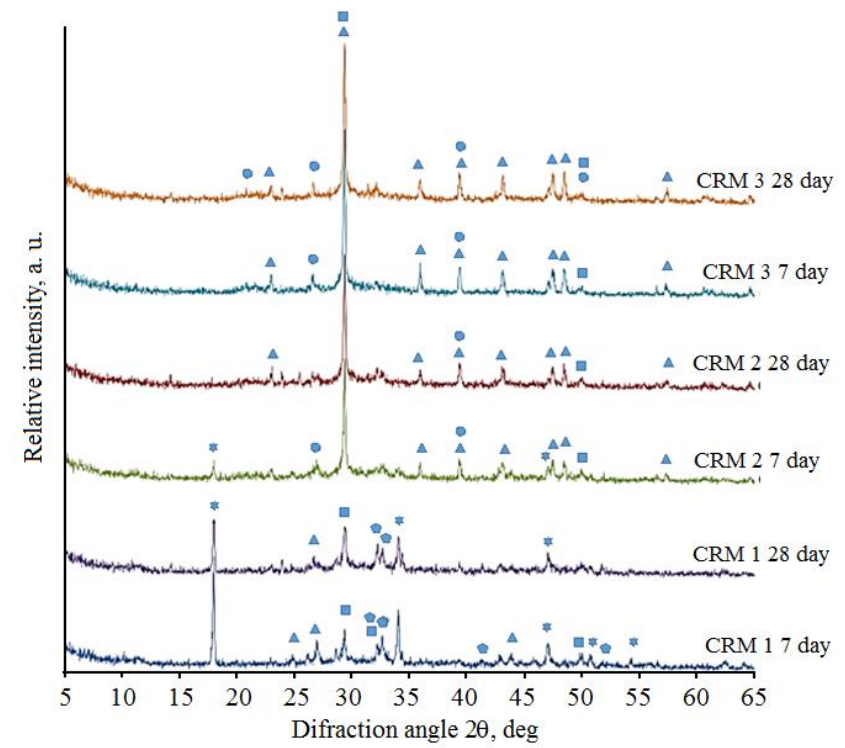

Fig. 4. X-Ray diffraction pattern of dried buckwheat husk concrete mixtures (CRM1, CRM2, CRM3) after 7 and 28 days of hydration. Indexes: $--\mathrm{SiO}_{2} ; \Delta-\mathrm{CaCO}_{3}$; - $\mathrm{CSH} ; \star-\mathrm{Ca}(\mathrm{OH})_{2} ;-\mathrm{C}_{3} \mathrm{~S}$

The experimental results show that after 28 days of hydration the compressive strength and dry bulk density of all specimens (without and with opoka replacement) of concrete without sand range within $2.91-3.08 \mathrm{MPa}$ and $809-925 \mathrm{~kg} / \mathrm{m}^{3}$, respectively. For concrete with an additive of sand, these values change within $5.86-7.35 \mathrm{MPa}$ and $1263-1410 \mathrm{~kg} / \mathrm{m}^{3}$, respectively. For all mixtures, there is satisfied the lower limit $\left(2.0-17.0 \mathrm{MPa}\right.$ and $\left.800-1440 \mathrm{~kg} / \mathrm{m}^{3}\right)$ to be used for structural/insulating purposes [3].

Results of investigations show that the properties of buckwheat husk concrete are better when not pure cement is used, but when $33 \%$ of cement is replaced with opoka.

In order to make a more exact estimation of the hydration process, dry samples for X-Ray analysis were prepared without the sand that is usually used. Specimens were ground to a powder, and the fibrous fraction (fibres of buckwheat husk) was eliminated using a $50 \mu \mathrm{m}$ sieve. 
The X-Ray diffraction investigation data (Fig. 4) show that the hydration of cement with opoka replacement is more complete, and after 28 days no peaks typical of initial cement minerals in X-Ray diffraction pattern curves of dried buckwheat husk concrete mixtures are identified.

\section{CONCLUSIONS}

A comparison of IR spectroscopy data of aqueous and alkaline buckwheat husk extracts' composition showed the prevalence of various polysaccharides. The dry extract yield in the buckwheat husk was $4.4 \pm 0.2 \%$ relative to the mass of the starting raw material.

The buckwheat husk extract increases both the initial and the final setting time of OPC. The partial $(33 \%$ and $50 \%$ ) replacement of cement with opoka significantly decreases the influence of the extract on the initial setting time and minimizes the influence on the final setting time.

The thermogravimetric investigation has revealed a strong modification and delay of silicate phase hydration by buckwheat husk extractives.

The test results show that the buckwheat husk aggregate and cement-opoka binding material combinations have a potential to be used in the production of a new lightweight concrete. The compressive strength of buckwheat husk concrete ranges from 3.0 to $8.0 \mathrm{MPa}$, and its dry bulk density changes from 800 to $1400 \mathrm{~kg} / \mathrm{m}^{3}$.

The results of the study show that better properties of buckwheat husk concrete are obtained when not pure cement is used, but when $33 \%$ of cement is replaced with opoka.

\section{REFERENCES}

1. Turgut, P. Cement composites with limestone dust and different grades of wood sawdust Building and Environment 42 (11) 2007: pp. $3801-3807$.

http://dx.doi:10.1016/j.buildenv.2006.11.008

2. Sisman, C.B., Gezer, E., Kocaman, I. Effects of Organic Waste (Rice Husk) on the Concrete Properties for Farm Buildings Bulgarian Journal of Agricultural Science 17 (1) 2011: pp. $40-48$.

3. Lamond, J.F., Pielert, J.H. Significance of Tests and Properties of Concrete and Concrete-making Materials. West Conshohocken, Pa.: ASTM, 2006: p. 664.

http://dx.doi.org/10.1520/STP169D-EB

4. Khedari, J., Suttisonk, B., Pratinthong, N., Hirunlabh, J. New Lightweight Composite Construction Materials with Low Thermal Conductivity Cement and Concrete Composites 23 (1) 2001: pp. $65-70$. http://dx.doi.org/10.1016/S0958-9465(00)00072-X

5. Payam, S., Hilmi, B.M., Mohd, Z.J., Majid, Z. Agricultural Wastes as Aggregate in Concrete Mixtures - A Review Construction and Building Materials 53 2014: pp. 110-117. http://dx.doi.org/10.1016/j.conbuildmat.2013.11.074

6. Karade, S.R. Cement-bonded Composites from Lignocellulosic Wastes Construction and Building Materials 24 2010: pp. $1323-1330$. http://dx.doi.org/10.1016/j.conbuildmat.2010.02.003

7. Zemnukhova, L.A., Tomshich, S.V., Shkorina, E.D., Klykov, A.G. Polysaccharides from Buckwheat Production Wastes Russian Journal of Applied Chemistry 77 (7) 2004: pp. $1178-1181$.

http://dx.doi.org/10.1023/B:RJAC.0000044171.74713.d8

8. Zemnukhova, L.A., Kolzunova, L.G., Shkorina, E.D. Extractive Substances Formed from Buckwheat Grain
Production Waste Russian Journal of Applied Chemistry 80 (6) 2007: pp. $1007-1011$.

http://dx.doi.org/10.1134/S1070427207060316

9. Zemnukhova, L.A., Shkorina, E.D., Fedorishcheva, G.A. Composition of Inorganic Components of Buckwheat Husk and Straw Russian Journal of Applied Chemistry 78 (2) 2005: pp. $324-328$.

http://dx.doi.org/10.1007/s11167-005-0284-1

10. Zemnukhova, L.A., Sukhoverkhov, S.V., Shkorina, E.D., Kovekhova, A.V., Tomshich, S.V. Use of High-performance Exclusion Chromatography for Analysis of the Molecular Mass of Polysaccharides Produced from Buckwheat and Sunflower Wastes Russian Journal of Applied Chemistry 80 (12) 2007: pp. 2051-2056. http://dx.doi.org/10.1134/S1070427207120108

11. Hromadkova, Z., Ebringerova, A. Ultrasonic Extraction of Plant Materials-investigation of Hemicellulose Release from Buckwheat Hulls Ultrasonics Sonochemistry 10 (3) 2003: pp. $127-133$. http://dx.doi.org/10.1016/S1350-4177(03)00094-4

12. Zemnukhova, L.A., Tomshich, S.V., Kovekhova, A.V., Greben, L.Yu. Polysaccharides Prepared from Sunflower Production Waste Russian Journal of Applied Chemistry 80 (7) 2007: pp. $1170-1174$. http://dx.doi.org/10.1134/S1070427207070300

13. Kuhne, G., Meier, W. Ursachen und Möglichkeiten zur Beeinflussung der Chemischen Wechselwirkungen in Holzfaserstoff-zement und Holzfaserstoff-gips-gemischen Holz als Roh- und Werkstoff 48 (4) 1990: pp. 153-158. http://dx.doi.org/10.1007/BF02627302

14. Collepardi, M., Monosi, S., Moriconi, G., Pauri, M. Influence of Gluconate, Lignosulfonate or Glucose on the $\mathrm{C}_{3} \mathrm{~A}$ Hydration in the Presence of Gypsum with or without Lime Cement and Concrete Research 14 (1) 1984: pp. 105-112. http://dx.doi.org/10.1016/0008-8846(84)90086-3

15. Vaickelionis, G., Martusevičius, M., Vektaris, B. Influence of Mineral Additives to Sawdust Properties Chemical Technology 6 (2) 1997: pp. 54-60 (in Lithuanian).

16. Vaickelionis, G., Vaickelionienè, R. Cement Hydration in the Presence of Wood Extractives and Pozzolan Mineral Additives Ceramics-Silikaty 50 (2) 2006: pp.115-122.

17. Barauskas, I. Influence of Pozzolana on the Hydration of $\mathrm{C}_{4} \mathrm{AF}$ Rich Cement in Chloride Environment Ceramics-Silikáty 57 (1) 2013: pp. $45-52$

18. LST EN 196-3:2005+A1:2009. Methods of testing cement-Part 3: Determination of setting times and soundness.

19. LST EN 196-1:2007. Methods of testing cement-Part 1: Determination of strength.

20. Jansen, D., Goetz-Neunhoeffer, F., Lothenbach, B., Neubauer, J. The Early Hydration of Ordinary Portland Cement (OPC): An Approach Comparing Measured Heat Flow with Calculated Heat Flow from QXRD Cement and Concrete Research 42 (1) 2012: pp. 134-138. http://dx.doi.org/10.1016/j.cemconres.2011.09.001

21. Ylmén, R., Wadsö, L., Panas, I. Insights into Early Hydration of Portland Limestone Cement from Infrared Spectroscopy and Isothermal Calorimetry Cement and Concrete Research 40 (10) 2010: pp. $1541-1546$. http://dx.doi.org/10.1016/j.cemconres.2010.06.008

22. Bullard, J.W., Jennings, H.M., Livingston, R.A., Nonat, A., Scherer, G.W., $\quad$ Schweitzer, J.S., $\quad$ Scrivener, K.L., Thomas, J.J. Mechanisms of Cement Hydration Cement and Concrete Research 41 (12) 2011: pp. 1208-1223. http://dx.doi.org/10.1016/j.cemconres.2010.09.011

23. Sauvat, N., Sell, R., Mougel, E., Zoulalian, A. A Study of Ordinary Portland Cement Hydration with Wood by Isothermal Calorimetry Holzforschung 53 (1) 1999: pp. 104-108. 